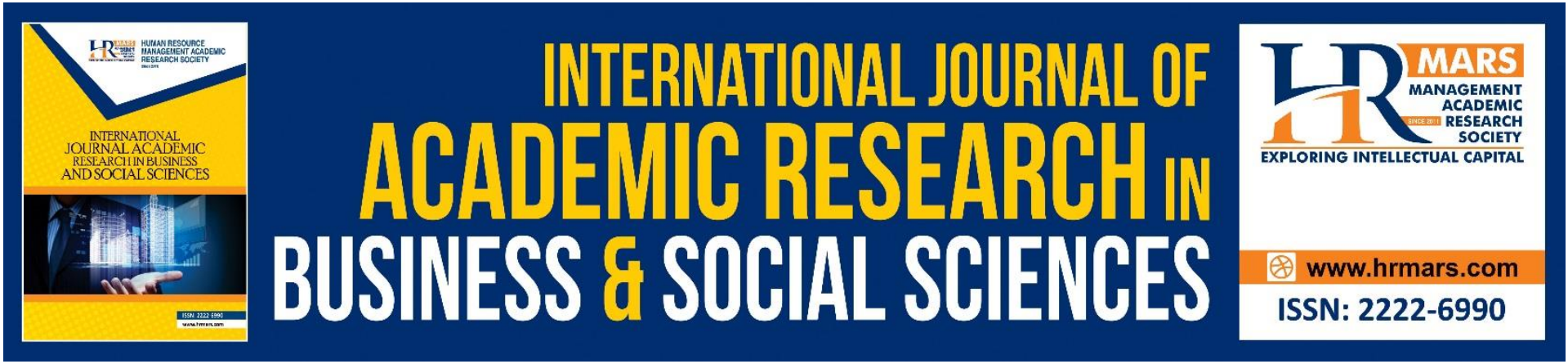

\title{
The Use of Augmentation in the Classroom: Ecopreneurer
}

\author{
Nalini Arumugam, Geraldine De Mello, Mohamad Idham Md Razak, \\ Mohammed Hariri Bakri
}

To Link this Article: http://dx.doi.org/10.6007/IJARBSS/v11-i10/11443

DOI:10.6007/IJARBSS/v11-i10/11443

Received: 09 August 2021, Revised: 27 August 2021, Accepted: 19 September 2021

Published Online: 13 October 2021

In-Text Citation: (Arumugam et al., 2021)

To Cite this Article: Arumugam, N., Mello, G. De, Razak, M. I. M., \& Bakri, M. H. (2021). The Use of Augmentation in the Classroom: Ecopreneurer. International Journal of Academic Research in Business and Social Sciences, 11(10), 727-741.

Copyright: (c) 2021 The Author(s)

Published by Human Resource Management Academic Research Society (www.hrmars.com)

This article is published under the Creative Commons Attribution (CC BY 4.0) license. Anyone may reproduce, distribute, translate and create derivative works of this article (for both commercial and non-commercial purposes), subject to full attribution to the original publication and authors. The full terms of this license may be seen at: http://creativecommons.org/licences/by/4.0/legalcode

Vol. 11, No. 10, 2021, Pg. $727-741$

Full Terms \& Conditions of access and use can be found at http://hrmars.com/index.php/pages/detail/publication-ethics 


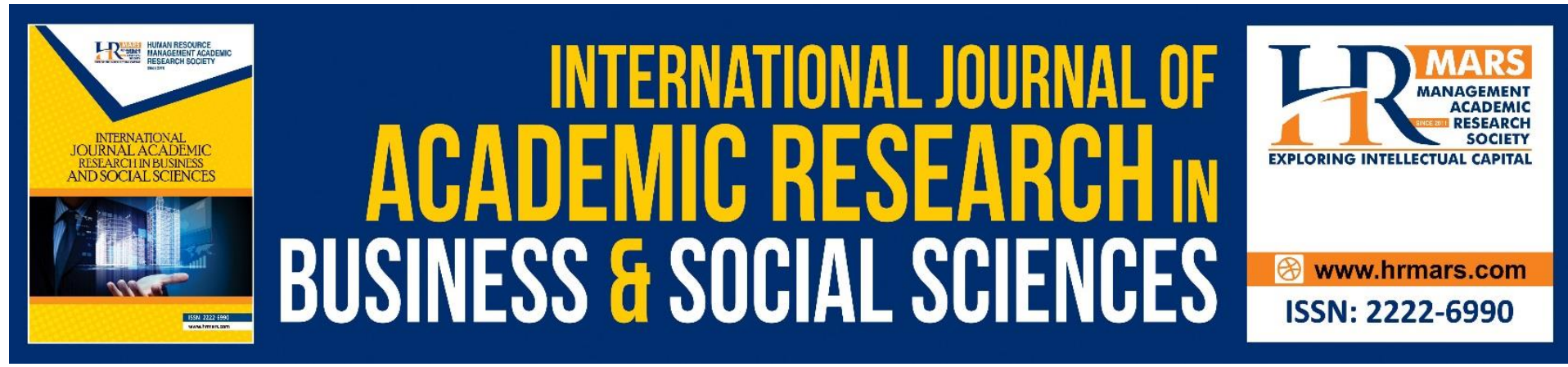

\title{
The Use of Augmentation in the Classroom: Ecopreneurer
}

\author{
Nalini Arumugam¹, Geraldine De Mello², Mohamad Idham Md \\ Razak $^{3}$, Mohammed Hariri Bakri ${ }^{4}$ \\ ${ }^{1}$ Academy of language Studies, Universiti Teknologi MARA Shah Alam, ${ }^{2}$ Academy of \\ Language Studies, Universiti Teknologi MARA Melaka, ${ }^{3}$ Faculty of Business and \\ Management, Universiti Teknologi MARA Melaka, ${ }^{4}$ Faculty of Technology Management \& \\ Technopreneurship, UTEM Melaka \\ Email: nalini@uitm.edu.my
}

\begin{abstract}
This study aims to bridge the gap by addressing the challenge which consists of internet connection excess and coverage, technology and computer skills, environment, motivation, time management, engagement with groupmates and educators, and the feedback on using artificial intelligence via Online Distance Learning. This study employed a mix-method approach to address the gap. As for quantitative part, 110 undergraduates who showed that they are knowledgeable in computer skills while qualitative design, five undergraduates and two instructors were selected randomly. The results indicated that the respondents are confident communicating electronically. They also expressed that they found it convenient to have group discussions outside the classroom to complete their group work. This reveals that the undergraduates are optimistic using arepreneurnomics platform which includes augmented reality. It is noteworthy that some of the respondents' experience poor internet connection, like unstable coverage and poor signal. Structured interview responses revealed that undergraduates found arepreneurnomics using augmented reality applications to be interesting, improves academic performance and challenging which encourage them to learn more about augmented reality. The educators shared that they need more training in AR not only using arepreneurnomics but also for other subjects as undergraduates are interested such applications. It can be concluded that the use of augmented reality can optimize conducive learning experiences for undergraduates with a pleasant learning experience while enhancing the engagement between educators and students. Both educators and undergraduates need more hands-on training in using augmented reality in classrooms to experience more benefits.
\end{abstract}

Keywords: Arepreneurnomics, Online Distance Learning, Augmented Reality, Engagement

\section{Introduction}

Augmented Reality (AR) is a technology of virtual objects that are superimposed upon or composited with the real world to give a real sense view for their user (Martins et al., 2015). There are three key features of the AR system, which are the mixture of the actual and the 
virtual, real-time interactive, and 3D-registered. Cabero (2015) states that AR is the simplified technology version of virtual reality (VR). Kangdon (2012) claimed that AR is the sense of a real environment with extended information and imagery from the system. Virtual reality (VR) is a fully immersive experience that obscures the physical world, whereas AR is a technological revolution in which virtual pictures are superimposed in the real world (Gonzalez, 2021).

Brush (2019) stated that the reconstruction of real-life events, objects, and aspects using a computer or mobile device to reinforce specific educational concepts is known as Augmented Learning ( $A L)$. $A L$ is the next phase for distance learning or better known as e-learning (Blum, 2018). Interactive learning aligns with the learning concept experience instead of attending virtual classes and completing the work. It aims to increase the likelihood of understanding since it's compatible with real-life experience. Brush (2018) posits that with a wide range of accessibility; smartphones and laptops can be used without any location restriction. Augmented learning apps use inputs and interactions as triggers to deliver specialized, related learning content to the end-user, such as voice recognition, touch recognition, and optical character recognition (OCR). The learning content is then presented to students as basic text and videos or as a three-dimensional (3D) virtual world in which they can engage to learn more.

\section{Background Study}

Babyboomer's teaching method is more to explaining using the whiteboard, books, still, photos, and other resources, where students just hear and try to comprehend the lessons and their understanding varies according to their maturity (Bistaman, 2018). Most of marketing education for learning is still primarily focused on linguistic cues such as written or spoken words. Although the old teaching method may still be helpful, the new and contemporary teaching method may give students a more effective way of learning as well as a more pleasant learning experience. Kunari (2006) argued that using visual aids in teaching is one method for improving lessons and providing students a clear picture to understand subject information. In consistent with this, Shabiralyani (2015) explained that students who are visual learners, prefer to be taught using diagrams, images, charts, flow charts, videos, and demonstrations which can be benefited by using AR software.

'If we hear, we forget; if we see, we remember; and if we do something, we know,' which indicates that the use of visual aids improves the effectiveness of the teaching-learning process (Jain, 2004). Bistaman (2018) indicated that past studies have seen AR technology as a viable method for increasing student enthusiasm and engagement, which would then help the teaching and learning process in an educational environment. AR technology is a computer-generated system that enables users to communicate with the physical and realworld around them. AR is typically capable of superimposing computer images onto the actual environment and allowing users to see the real world as well as virtual imagery connected to real-world locations and objects (Kaufmann, 2011).

\section{Augmented Reality in the Classroom}

Technology has now found its way into the classroom, where it is evolving at an exponential rate, improving the interactive and engaging features that can give benefits to students (Blum, 2018). Undergraduates are exposed to and familiar with numerous devices and technology in everyday life, including computers and smartphones. The introduction of technology increases the likelihood of students attending classes by 87 per cent and participation by 72 
per cent, which is why computerized tools and apps make sense in a classroom setting (Eastman, 2009).

Bistaman, (2018) reckoned that teaching and learning process should be improved in conjunction with technological advancements to ensure that future generation of students are exposed to a wide range of aspects, especially AR so that the students be abreast with technology and are knowledgeable. The use of AR in the classroom can benefit students in various ways, especially in handling projects.

\section{Statement of Problem}

$A R$, on the other hand, includes thinking abilities and allows students to experience learning using applications and other augmented tools. AR technology produces images or objects that are then blended into a real-world environment (Bistaman, 2018). AR differs from the conventional learning method in that the conventional learning method is mostly focused on books, with students just reading and listening to their teachers. With the increasing use of personal mobile devices in today's world, the huge potentials of AR have begun to be explored, as smart devices can generate AR environments. Advanced AR technology is widely used in developed countries such as Europe. Neha et al. (2015) concurred that Indians intended to develop adversity of AR features in mobile Android-based applications and marker-based library applications. In Bangladesh, 'Rise Labs' has developed an AR application called "1952-History of 1952 in Augmented Reality" (Sharif, 2018). Although AR projects are being employed in many developed countries' education sectors, they have yet to be expanded in developing countries. In Malaysia, the teaching and learning process is still based on the conventional verbal educational method, which is not always effective. Indeed, many educational institutions continue to use inefficient methods of delivering lectures, which results in a lack of student engagement. Despite all the challenges of using augmented reality in the classroom, most users have found the application to be beneficial, particularly in the teaching and learning context. However, not much has been done in integrating AR in the classroom in Malaysia. Hence, this study aims to bridge the gap by addressing the following questions:

1.What are the student's perceptions of the implementation of Augmented Reality in the classroom?

2. What are the challenges faced by students during an augmented learning activity?

3. To what extent will the implementation of Augmented Reality in the classroom enhance teaching and learning?

\section{Methodology}

This study used a mix-method approach to collect data from undergraduates and educators who used arepreneurnomics to learn economics. The respondents are from the Faculty of Business Management. Data were collected from 110 undergraduates who learned economics via online arepreneurnomics platform via google form to answer research question one. Structured interviews were also conducted randomly among five students and two educators to answer research question 3. The Undergraduates respondents are identified as the following: Undergraduates as S1, S2, S3, S4 and S5 while Educators as E1 and E2. The identity of all respondents was kept confidential. 


\section{Instruments}

A set of questionnaires was adapted from Arumugam, et al., (2020) and was distributed among 110 undergraduates from the Faculty of Agriculture to learn about the respondents' views regarding online learning. The questionnaire consisted of three parts: Part I of the questionnaire was designed to gather information about students' demographic information, Part II aimed to gather information about the perceptions of undergraduates on the use of arepreneurnomics to learn economics while Part III was designed to gather information about challenges faced by respondents in using arepreneurnomics which consists of AR apps. Both Part II and III were structured in the Likert Scale, on a 4 - point scales, ranging from strongly agree, agree, disagree and strongly disagree. Later the responses were merged into two categories: strongly agree and agree for agree responses, and strongly disagree and disagree for disagree responses. The collected data from the questionnaire were analysed using descriptive analysis. A credibility test was performed, and Cronbach's Alpha for the questionnaire is 0.803 , indicating that the questionnaire's internal consistency is reliable. The data was collected using Google Forms.

\section{Results and Discussion}

Gonzalez (2021) reckoned that AR aids educators to teach, encourage and improve student interaction in the classroom despite the type of classes and students' abilities by inducing practical, memorable, and engaging learning activities.

\section{Students' Positive Perceptions of Augmented Reality}

Brush (2019) affirmed that AR can produce short, interactive content that is easy to understand and reinforces lengthier core learning material. 
Table 1: Student's perception towards Arepreneurnomics used in the classroom.

\begin{tabular}{|c|c|c|c|}
\hline & Questions & $\begin{array}{l}\text { Agree } \\
(\%)\end{array}$ & $\begin{array}{l}\text { Disagree } \\
\text { (\%) }\end{array}$ \\
\hline 1 & I am good at using the computer. & 97.27 & 2.73 \\
\hline 2 & I am comfortable communicating electronically. & 83.63 & 16.37 \\
\hline 3 & $\begin{array}{l}\text { I believe a complete course (ENT600 AND ECO415) can be given } \\
\text { over online without difficulty. }\end{array}$ & 62.97 & 37.03 \\
\hline 4 & $\begin{array}{l}\text { I can discuss with other students during (ODL) Internet activities } \\
\text { outside classroom. }\end{array}$ & 89.09 & 10.91 \\
\hline 5 & $\begin{array}{l}\text { I can work in a group during (ODL) Internet activities outside of } \\
\text { classroom. }\end{array}$ & 83.64 & 16.36 \\
\hline 6 & I can easily complete assignments on time. & 75.45 & 24.55 \\
\hline 7 & I enjoy using arepreneurnomics. & 91.82 & 8.18 \\
\hline 8 & I am comfortable using arepreneurnomics. & 86.36 & 13.64 \\
\hline 9 & I am willing to explore more about arepreneurnomics. & 94.55 & 5.45 \\
\hline 10 & Using arepreneurnomics enhanced my learning of economics. & 89.1 & 10.91 \\
\hline 11 & $\begin{array}{l}\text { Augmented Reality platform like arepreneurnomics should be } \\
\text { included in Economics and Entrepreneurship programs. }\end{array}$ & 92.73 & 7.27 \\
\hline 12 & $\begin{array}{l}\text { Augmented Reality in arepreneurnomics encouraged me to use } \\
\text { this application frequently. }\end{array}$ & 92.73 & 7.27 \\
\hline 13 & $\begin{array}{l}\text { Augmented Reality application in arepreneurnomics was easy to } \\
\text { use. }\end{array}$ & 92.73 & 7.27 \\
\hline 14 & I learn to use Augmented Reality in arepreneurnomics fast. & 82.72 & 17.27 \\
\hline 15 & I am confident using Augmented Reality in arepreneurnomics. & 84.55 & 14.55 \\
\hline
\end{tabular}

Table 1 shows that most of the students (97.27\%) agree that they are good at using computers while only $2.73 \%$ of them disagree. The majority of the students (83.63\%) also admitted that they are comfortable communicating electronically. This shows that students are capable of accepting augmented reality as a new learning method. The use of AR in the classroom will lead to a positive attitude among the students who will find it interesting and easier to understand the subject taught. This result is aligned with Blum (2018) who asserted that students nowadays are digital-savvy which makes digital tools and applications easy to access. 
Over three-quarters of the students (89.09\%) agreed that they can have discussions with group mates during internet activities outside the classroom and $83.64 \%$ of them admitted that they can commit to group work. Although it is still new, the learning activities do not hinder communication between teachers and classmates. Additionally, being able to communicate well with their classmates and doing group work will further enhance their motivation to study. These results are supported by Brush (2018) who posited that students can still communicate with teachers and classmates in the learning environment proposed by AR.

Most of the students (75.45\%) are positive that they are able to complete economics assignments on time without difficulty while $91.82 \%$ shared that they enjoyed learning economics via arepreneurnomics and $86.36 \%$ of them assured they are comfortable using AR in arepreneurnomics. As students nowadays are exposed to the digital world, students always find that augmented reality is easily accessible, appealing, and effective to use in the learning process. This will further help them in understanding and liking the subject more and scoring high marks in their exams. Apart from finding teaching lessons helpful and engaging, AR can also make students gain a deeper understanding and memorize information better as the content is related to the real world (Blum, 2018).

$A R$ also improved the learning process in students as $89.1 \%$ of them admitted that using arepreneurnomics has enhanced their learning in economics. Compared to traditional ways, augmented reality makes the learning process more fun, looks real, and reduces stress as the content of the subject is well illustrated and easy to understand. Furthermore, students will be motivated to learn more as they find the lessons interesting. Brush (2018) stated that augmented reality simplified the learning activity without any complicated process and expensive tools needed. A high percentage of students $(92.73 \%)$ voiced that arepreneurnomics not only made economics learning easier but also encouraged them to use the app frequently. Blum's (2018) argument is in line with this when he pointed out that students can understand the subjects and ideas well through the simulation of augmented reality as AR can also alleviate the limited access to the high-cost practical demonstration. The use of AR makes them feel more relaxed and enjoy the learning process without feeling pressured. In addition, mistakes made by students during the learning process would not cost a penny as there are no consequences to the students in the virtual world (Brush, 2019; Shabiralyani, 2015).

The results indicate that the majority of the undergraduates find $A R$ in the classroom beneficial for them. When learning through $A R$, students and educators opt to use interactive methods and develop special content with a specific approach that can increase the effectiveness of the learning. Students can complete their tasks easily as they completely understand the subject and can relate it to real life. In this digital era, augmented reality has become an inspiring educational method to students as they seldom leave their gadgets. Brush (2021) asserts that AR provides a platform for students to organize their educational environment to obtain intense understanding and bridge the gap between theoretical and practical learning thus enabling them to apply what they learned to real-life situations.

However, students and educators who find it difficult, may need extra guidance and training to follow their lessons using AR. A similar situation has been raised by Martins et. al (2015) 
and (Sharif, 2018) where they stated that it is necessary for hands-on training in familiarizing AR tools in the education field.

\section{Challenges in Using Augmented Reality}

According to Martins et al. (2015), there have been challenges faced by both students and teachers in terms of technological, sociocultural, pedagogical, and management areas. There is a challenge for educational professionals because solutions for any problems related to AR tools require high technical knowledge and considerable time to generate content. This is because the AR tools are developed by computer experts and even though the educational apps were done by consulting education professionals, the apps are more likely to be influenced by computer specialists. However, the challenges can be overcome by having more groups of educators brainstorming and coming up with an endless amount of content for AR. This is supported by the works of Sommerville (2001) and Pressman (2001) that relates that there is a gap between the development of software for interactive applications and users in the education field. Other than that, it is said that there is a concern over students becoming too dependent on technology due to the usage of AR in educational platforms.

Figure1: Challenges of the accessibility of the Internet

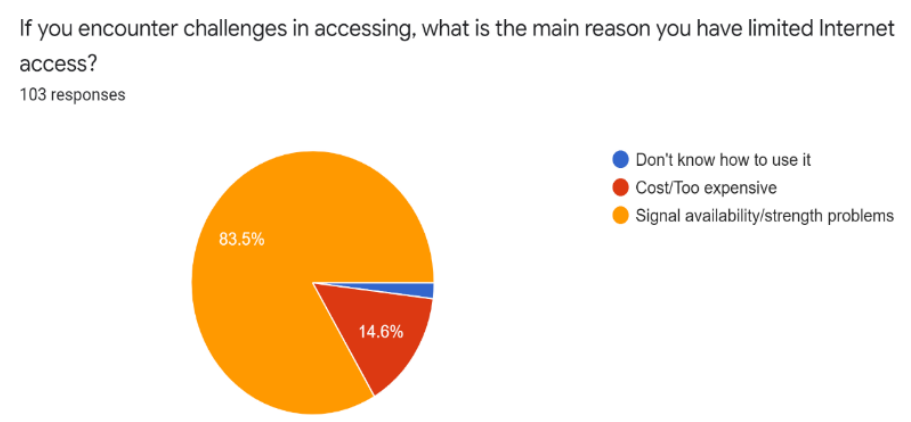

Figure 1 shows that $83.5 \%$ of students shared that the main challenge is the Internet access, connection strength and signal availability while $14.6 \%$ of them revealed their financial constraint as their main problem. Only $1.9 \%$ indicated that they are illiterate in using the app. Perhaps the challenges exist due to their socioeconomic background. Martins et. al (2015) highlighted that it is important to make sure that everyone in the classroom has equal access to technology.

Figure 2 Challenges faced with Internet connection

Do you have strong and fast Internet access at home? *Here strong and fast internet access refers to accessing through digital subscriber line (DSL, ... and VDSL), internet access cable or fiber to home 110 responses

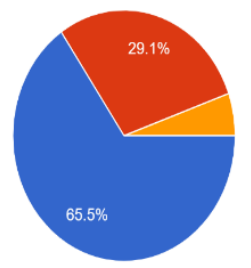

- Yes

- Limited (Access through mobile phone or hand held device)

№ 
Figure 2 shows that $65.5 \%$ of the students have strong and fast Internet access at home and $29.1 \%$ of them have limited access to Internet connection which is by using mobile phone while 5.4 indicated that they do not have access at all. This once again shows that not every student has equal access and conditions to accessing the Internet for their online classes.

Table 2 Challenges faced by students towards Arepreneurnomics used in the classroom

\begin{tabular}{|l|l|l|}
\hline Questions & $\begin{array}{l}\text { Agree } \\
\text { (\%) }\end{array}$ & $\begin{array}{l}\text { Disagree } \\
\text { (\%) }\end{array}$ \\
\hline Learning is the same in class and at home over the Internet (ODL) & 26.61 & 73.39 \\
\hline $\begin{array}{l}\text { Learning over the Internet outside classroom is more motivating } \\
\text { than a regular course }\end{array}$ & 39.09 & 60.91 \\
\hline $\begin{array}{l}\text { Face-to-face contact with my instructor is necessary for effective } \\
\text { learning to occur }\end{array}$ & 89.09 & 10.91 \\
\hline $\begin{array}{l}\text { I am able to manage my study time effectively online and easily } \\
\text { complete assignments on time }\end{array}$ & 89.09 & 10.91 \\
\hline $\begin{array}{l}\text { I am left behind compared to my classmates (peers) in using } \\
\text { arepreneurnomics }\end{array}$ & 59.1 & 40.9 \\
\hline $\begin{array}{l}\text { I found Augmented Reality application in arepreneurnomics } \\
\text { unnecessarily complex }\end{array}$ & 68.18 & 31.82 \\
\hline $\begin{array}{l}\text { Augmented Reality functions were inconsistent in } \\
\text { arepreneurnomics }\end{array}$ & 69.09 & 30.91 \\
\hline $\begin{array}{l}\text { I found augmented Reality in arepreneurnomics } \\
\text { cumbersome/awkward to use }\end{array}$ & 56.36 & 43.64 \\
\hline
\end{tabular}


Table 2 shows that the majority of the students disagree that learning is the same in class and at home over the Internet (ODL) as $73.39 \%$ of the students disagree to this item while a fair share of a total of $26.61 \%$ students agree. This relates to the next question where a total of $60.9 \%$ of students disagree that learning over the Internet outside the classroom is more motivating than a regular course. Only $39.09 \%$ of students agree to this item. These responses express that learning via the Internet at home is not favoured by students as they perceive it to be less effective compared to the traditional way of learning in the classroom instead. The students also need more time to get familiarised with fully online learning. This was pointed by Martins et. al (2015) where they highlighted that it is very important to promote safe and healthy technology usage to avoid this from hampering their study.

Next, $89.09 \%$ of students agreed that face-to-face contact with the instructor is necessary for effective learning to occur while only $10.91 \%$ of students disagreed to this statement. Faceto-face learning is still favored by students as they feel more confident seeing and being with their classmates and having the lecturer teach in front of the class. This further strengthens the previous items that studying over the Internet is not effective as they are more comfortable receiving guidance from their instructors in the classroom. One of the reasons why studying over the Internet is not effective brings us to the next item where a total of $53.63 \%$ of students stated that having online fully is challenging as they are unable to manage their study time and cannot easily complete their assignments on time (46.36\%). This explains that a large number of students are not able to manage their studies well with online learning and this may be due to the distractions that they face where ever they are at the time of their online classes.

Furthermore, $59.1 \%$ of students admitted that they feel that they are left behind compared to their classmates in using Arepreneurnomics. However, $40.91 \%$ of students perceive this item otherwise. This shows the next challenge is students' familiarity in using AR. If they are not AR-savvy they often feel left-behind their peers in the classroom. This also hints that not all Gen Y students are AR savvy. A total of $65.45 \%$ of students said that they found augmented reality applications in Arepreneurnomics to be very complex while $69.09 \%$ of students agreed that augmented reality functions were inconsistent in Arepreneurnomics. Again, students' responses reveal that not everyone enjoys learning through AR. Moreover, it can be interpreted that students need to have knowledge in AR and the software for them to explore it. This also hints the Arepreneurnomics developers to look into AR consistency and use necessary apps only. Martins et. al (2015) too argued that to run an AR software needs technical knowledge and to have customised AR educational applications tailored to each student and subject needs, a combination of both computational technical knowledge and the knowledge of the subject is needed to develop such contents. It is also noteworthy that most of the software-making tools are not easy to use. This is a challenge in terms of the pedagogical area and solutions must be made to overcome these problems so that an effective AR learning environment can be achieved. Although students encounter some challenges in learning via $A R$, it undoubtedly excites students in the teaching and learning process as well as enriches engagement in classrooms. Therefore, it is advisable for established higher learning institutions to provide students and teaching staff with sufficient training and materials to prepare them for the new era in teaching and learning endeavour. 


\section{Research Question 3}

To what extent will the implementation of Augmented Reality in the classroom enhance teaching and learning?

The education arena has witnessed a transformation due to continuous technological advancement. An app like arepreneurnomics can elevate education especially ODL in the current COVID-19 pandemic in various ways. Two instructors and five undergraduates who used Arepreneurnomics were randomly selected to participate in structured interviews to get an insight before suggesting it to all classes of economics. The analysis of the structured interview responses led to three major themes; interesting, enhance academic performance and challenges.

\section{Interesting}

E1 said that "I am confident using Augmented Reality in arepreneurnomics. I found the various Augmented Reality functions in arepreneurnomics were well integrated and I personally feel that Augmented Reality platform like arepreneurnomics should be included in Economics and Entrepreneurship programs to attract young students, undergraduates.

E2 said, "AR technology plays a significant role in the students' learning as the visual quality of $A R$ in arepreneurnomics is good in explaining the process. I feel this will affect students' grasp and this will increase students' understanding in learning Economics \& Entrepreneurship." Bistaman (2018) too said that with AR students can remember better as they will both enjoy what they are learning and at the same time understand what is being taught.

S1 said he is very interested to study Economics and Entrepreneurship especially arepreneurnomics. It is very exciting and user-friendly. This shows that using $A R$ in arepreneurnomics attracts students' attention to learn and understand the subject better and relate well to questions put forward to them. Augmented reality can emphasize critical concepts in a textbook with 3D images and breaks the stigma of textbook learning that is seen as mundane and tedious by many students (Sharif, 2018).

\section{Academic Performance}

Shabiralyani (2015) explained that students who are visual learners, prefer to be taught using diagrams, images, charts, flow charts, videos, and demonstrations which can be benefited by using AR software.

Respondents also commented on the pedagogies and strategies that they used with AR. Both E1 and E2 reported that their classes performed well in the final examination compared to their previous semester. In addition, they revealed that their class had $97.5 \%$ and $98.8 \%$ respectively passing grades.

E1 said, "My class students most of them managed to do their final project well and scored high marks in the final examination too." 
E2 added, "My students too did well. I believe that arepreneurnomics has helped them to understand the subject better. I used AR via arepreneurnomics to "introduce a concept", "set the context for learning" or "to activate prior knowledge" and "real cottage business". Both E1 and E2 also conveyed that they found AR useful for visualization particularly for "exploring structures we can't get to" or "places we can't go" (especially during the pandemic). They also noted that they were using AR for teaching entrepreneurship via gamification and role play using favourite persona for GenY. This is in line with Mundy, Hernandez and Green (2019) who affirmed that with the inclusion of AR will improve student's academic performance.

S1, S2 and S4 indicated that arepreneurnomics platform has guided them in learning Economics \& Entrepreneurship education. The use of AR in arepreneurnomics gave them a vivid imaginary of real situation, discussion and concepts involved in ENT. S1 agreed that arepreneurnomics enhanced her knowledge in ENT. "I am not very good in ENT subject but learning via arepreneurnomics guided me well. Moreover, the concepts showed in arepreneurnomics facilitated me in completing my project satisfactorily. I believe this time I will get a good grade."

S2 and S4 too reckoned that arepreneurnomics consists of good information and exercises provided are very useful. "Just reading the notes will be a bit boring (hihihi giggling). But learning via arepreneurnomics is interesting. So, I login more than my class time," said S4. This shows that the implementation of AR gives a good perception of students' academic progress and increases their motivation to study. With the use of AR in the classroom, students find that lessons are more interesting and easier to follow. Therefore, the students can learn faster and grasp more when AR is used. Bistaman (2018) reckoned that teaching and learning process should be improved in conjunction with technological advancements to ensure that future generation of students are exposed to a wide range of aspects, especially AR so that the students be abreast with technology and knowledgeable. The use of AR in the classroom can benefit students in various ways, especially in handling projects.

\section{Challenges}

Users of AR technology may experience usability issues and technical problems, and some students may find this technology complicated (Akçayır \& Akçayır, 2017). They also further explained that one of the main challenges of AR applications is usability.

S5 and S3 said they encountered some challenges and needed help in use arepreneurnomics. They were very lost in the initial stage. However, after some time like three weeks, "I started learning the platform by reading it online and also asking my classmates" said S5.

"I needed to learn a lot of Augmented Reality skills in arepreneurnomics before I could get going with this application. I have been calling my friends and classmates to learn the procedures. But after week 6, I managed it myself. Of course, I had problem on and off", said S3.

S4 often faced internet interruption as he lives in outskirt. "Sometimes, I face a lot of difficulties especially during rainy days. It may take time and if I had to submit my work pertaining to arepreneurnomics, I must wait for a good weather," said S4. 
E1 and E2 too shared that many times students complained that they were unable to access due to poor internet connection. "My class students many of them complained that arepreneurnomics needs higher data and they need to reload data often when they login to Augmented Reality," said E2.

Akçayır and Akçayır (2017) and Wu, et al. (2013) illustrated that some difficulties may be encountered if the technology lacks well-designed interfaces and guidance as this may result in the technology being too complicated. Besides, users may also need time to get familiar and comfortable with AR technology.

\section{Conclusion}

The use of $A R$ as an educational tool in the classroom brings a fun learning experience for students and teachers without neglecting the objective of the lesson plan under efficient cost and time. The use of AR can optimize conducive learning experiences for students too. The employment of $A R$ in the classroom may provide a pleasant learning experience while also assisting teachers in improving classroom engagement for students. However, presented with the challenges faced, it is important to acknowledge the challenges in implementing AR in classrooms and also find solutions to create a more effective learning environment for both educators and students. All in all, AR should be implemented and utilized in every classroom since it improves student engagement and has many other benefits that can give a shift to the traditional education system by improving the entire learning experience.

\section{Implication}

This study provides insights that AR integrated Arepreneurnomics which can be used by mobile app to enhance students' understanding of the importance of information and visual quality of visuals. Furthermore, this study suggests that high quality used in the Arepreneurnomics can lead to better performance and degrades among undergraduates. The current study contributes to closing a knowledge gap by considering AR technology as an important factor in the success and effectiveness of integrating AR in classrooms.

\section{Recommendation}

From the results and findings of this study, the implementation of AR in the classroom should be reinforced as it gives plenty of positive effects on students' academic performance. It is also recommended to be taught in all formal institutions and be included in the course syllabus so that all students can fulfill the demand of today's digital era. Nevertheless, thorough guidance on augmented learning should be given to teachers and students so that they will not be left behind. Besides, teachers also play a vital role to make sure that the learning process is interactive and all students can commit to group work. As the use of AR is new, seminars to tackle its challenges should be held twice a year to improve the teaching process.

\section{References}

Akçayır, M., \& Akçayır, G. (2017). Advantages and challenges associated with AR for education: a systematic review of the literature, Educational Research Review, 20, 111. 
Blum, A. (2018). The Multiple Uses of Augmented Reality in Education. https://www.emergingedtech.com/2018/08/multiple-uses-of-augmented-reality-ineducation/.

Brush, K. (2019). Augmented learning. https://searchhrsoftware.techtarget.com/definition/augmented-learning

Desai, A. (2018). Animation in Education. Retrieved from CG Pundit: https://www.cgpundit.com/animation-in-education/

Cabero, J. (2015). The educational possibilities of Augmented Reality. New Approaches In Educational Research, 5(1), 44-50. DOI: 10.7821/naer.2016.1.140

Eastman, J. K., lyer, R., \& Eastman, K. L. (2009). Interactive technology in the classroom: An exploratory look at its use and effectiveness. Contemporary Issues In Education Research - Third Quarter 2009, 2(3), 31-38.

Gopalan, V., Zulkifli, A. N., \& Abubakar, J. A. A. (2016). A study of students' motivation using the AR science textbook. AIP Conference Proceedings, 1761 (1), 27-35.

Jain, P. (2004), Educational Technology, Delhi Moujpur publication.

Kaufmann, H. (2011) Journals Collaborative Augmented Reality in Education Institute of Software Technology and Interactive Systems (Vienna University of Technology: Favoritenstrasse) 9-11/188.

Mundy, M. A., Hernandez, J., \& Green, M. (2019). Perceptions of the Effects of Augmented Reality in the Classroom, Journal of Instructional Pedagogies, 22, 1 -15.

Neha, R. T. (2015), Augmented reality in context to india. International Journal of Innovative Research in Computer and Communication Engineering, 3, 6674-6675,

Martins, V. F., Gomes, L., \& Guimarães, De P. M. (2015, June). Challenges and possibilities of use of augmented reality in education case study in music education. In International Conference on Computational Science and Its Applications (pp. 223-233). Springer, Cham.

Kangdon, L. (2012). (PDF) Augmented reality in education and training. ResearchGate. https://www.researchgate.net/publication/257692981_Augmented_Reality_in_Educ ation_and_Training

Kirner, C. (2013). A educação permeando a tecnologia em aplicações educacionais abertas baseadas em hipermídia e realidade aumentada. Revista Contemporaneidade, Educação e Tecnologia, 1(3), 75-87.

Pressman, R. S. (2005). Software engineering: a practitioner's approach. (5th ed.) New York, USA: McGraw-Hill

Shabiralyani, G., Hasan, S. K., Hamad, N., \& Iqbal, N. (2015). Impact of Visual Aids in Enhancing the Learning Process Case Research: District Dera Ghazi Khan. Journal of Education and Practice, 6 (19), 226-233.

Sharif, A., Anzum, F., Zavin,A., Suha, S. A., Ibnat, A., Islam, M. N. (2018). Exploring the Opportunities and Challenges of Adopting Augmented Reality in Education in a Developing Country. 10.1109/ICALT.2018.00091.

Sommerville, I. (2001). Software Engineering (6th ed.) Boston, USA: Addison-Wesley Longman Publishing Co., Inc.

Sun, D., Xu, L., Zhang, L., \& Cui, N. (2019). How Augmented Reality Affects People's Perceptions: Adoption of AR in Product Display Improves Consumers' Product Attitude. Journal of Physics: Conf. ICNISC2019 IOP Conf. Series: Series 1288 (2019) 012037 IOP Publishing doi:10.1088/1742-6596/1288/1/012037 1 
INTERNATIONAL JOURNAL OF ACADEMIC RESEARCH IN BUSINESS AND SOCIAL SCIENCES

Vol. 11, No. 10, 2021, E-ISSN: $2222-6990$ @ 2021 HRMARS

Wu, H., Lee, S., Chang, H., \& Liang, J. (2013). Current status, opportunities and challenges of AR in education. Computers and Education, 62, 41-49. 